\title{
Research on the Applications of Humanistic Care and the Moral Motivation on University Student Management
}

\author{
Penghui Zhang ${ }^{1}$ \\ ${ }^{1}$ agricultural university of hebei, \\ Baoding City, Hebei Province, 071001 China
}

\begin{abstract}
In this paper, we conduct research on the applications of humanistic care and the moral motivation on university student management. The basic task of colleges and universities is to cultivate people. Facing the reality of ideological and cultural diversity, many university students' ideological and political workers generally feel students work is more than hard to undertake. Student management in colleges and universities need to accurately understand and grasp the students' actual demand and psychological state. Our research provide the managers the state-of-theart methodology to take as the reference to help them work more effective in the daily working activities.
\end{abstract}

Keywords: Humanistic Care; Moral Motivation; Student Management; Literature Review.

\section{Introduction}

Along with the social development and the network popularization, the students come into contact with the ideas presented the trend of diversification, scale and enrollment expansion of colleges and universities in recent years is the university is more and more big, the large population base, the students create a greater students individual differences of their thoughts and actions become increasingly diversified, the traditional college student management mode no longer adapt to the development trend of modern colleges and universities. The increased level of students, psychological problems focusing on hot issues variety is a dual factors theory of driver used in student management in colleges and universities. The basic task of colleges and universities is to cultivate people. Facing the reality of ideological and cultural diversity, many university students' ideological and political workers generally feel students work is more than hard to undertake. Fact reminds us, the student management in colleges and universities and the ideological education work, just like the used to meet again in the general routine management, ineffective. Therefore, for the power, we should change ideas to analyze the new situation, study new problems, in order to strengthen the management of students and the effectiveness of the ideological education which becomes the important topic of students' ideological and political work of institutions of higher learning. Student management system is the basis of students learning, also be the basis of in daily management of colleges and universities. In an open mind, freedom of the campus atmosphere, the establishment of the student management system needs to build on the basis of the scientific and democratic. Scientific and reasonable, the student as the main body of the management system can not only realize the effective management to the student and we can also realize the students' self-management methodology to build a harmonious campus atmosphere which will be meaningful and feasible [1].

The ultimate goal of college education is to make its social attribute and the social ability, become a society really need high-quality talent, so colleges and universities need to be carried out in accordance with the laws of education and market in-depth reform, establishing a high 
level of teaching and scientific research team. First of all, the school should set up a high academic level of teachers' team to the talent training mode for research center and key gradually establish the academic leaders as the core mechanism of academic team. Secondly, the construction of the high levels of teachers from its own mining and foster, set up relevant professional training for teachers of college education, on the other hand to introduce appropriate policies, absorption and the introduction of part-time teachers high level talents, build a high level of teaching and scientific research team. Management psychology theory, the evaluation is an important means to mobilize students' enthusiasm creativity and subjective initiatives to mobilize the initiative of the students need to use a certain incentive evaluation mechanism. Student management in colleges and universities need to accurately understand and grasp the students' actual demand and psychological state, make most of the student recognition which needs fair incentive evaluation system, stimulate students' sense of identity. Incentive evaluation should not only include the students' classroom learning and the content of the study result, also including students' extracurricular activities and social activities of their comprehensive quality and cultivate the students' comprehensive qualities [2-3].

In this paper, we conduct research on the applications of humanistic care and the moral motivation on university student management. The ultimate purpose of education is to realize the all-round development of human beings, the ultimate goal of university education is to realize the comprehensive development of college students and progress. Today's society is a diversified development of society, in the diversification of education method, education method and education value, so in the process of higher education, should adhere to the peoplecentered concept to promote the implementation of humanized management and consolidate students. In the following sections, we will discuss the issues from different perspectives.

\begin{tabular}{|c|c|c|c|c|c|c|}
\hline & Sub-system & \multicolumn{2}{|c|}{ branch system } & \multicolumn{3}{|c|}{ Thematic work } \\
\hline & \multicolumn{2}{|c|}{ Grade-one module } & \multicolumn{2}{|c|}{ Grade-two module } & $\begin{array}{l}\text { Grade-three } \\
\text { module }\end{array}$ & Grade-four module \\
\hline & \multicolumn{6}{|c|}{ Educational work system } \\
\hline \multirow{10}{*}{ 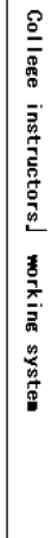 } & \multirow{10}{*}{ 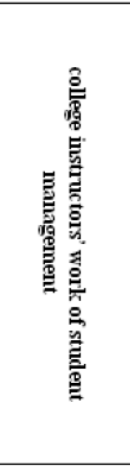 } & \multirow{2}{*}{\multicolumn{2}{|c|}{$\begin{array}{l}\text { Establishment } \\
\text { and } \\
\text { management of } \\
\text { class, the Party } \\
\text { and the League }\end{array}$}} & \multicolumn{3}{|c|}{ Establishment and management of class } \\
\hline & & & & \multicolumn{3}{|c|}{$\begin{array}{l}\text { Establishment and management of the Party and the } \\
\text { League }\end{array}$} \\
\hline & & \multirow{2}{*}{\multicolumn{2}{|c|}{$\begin{array}{l}\text { Information } \\
\text { management }\end{array}$}} & \multicolumn{3}{|c|}{ Basic Information Management } \\
\hline & & & & \multicolumn{3}{|c|}{$\begin{array}{l}\text { Students management platform (software), data entry and } \\
\text { management }\end{array}$} \\
\hline & & \multirow{2}{*}{\multicolumn{2}{|c|}{$\begin{array}{l}\text { Management of } \\
\text { code of } \\
\text { conduct } \\
\text { development }\end{array}$}} & \multicolumn{3}{|c|}{ Management of civilized behavior development } \\
\hline & & & & \multicolumn{3}{|c|}{ Management of health habits development } \\
\hline & & \multirow{4}{*}{\multicolumn{2}{|c|}{$\begin{array}{l}\text { Management of } \\
\text { daily affairs }\end{array}$}} & \multicolumn{3}{|c|}{$\begin{array}{l}\text { Student comprehensive assessment, regular schedule } \\
\text { supervision }\end{array}$} \\
\hline & & & & \multicolumn{3}{|c|}{$\begin{array}{l}\text { Awards, scholarship, loans, grants, financial aid to poor } \\
\text { students }\end{array}$} \\
\hline & & & & \multicolumn{3}{|c|}{ Coordination, liaison, approval of procedures, signature } \\
\hline & & & & \multicolumn{3}{|c|}{ Security, stability, emergency handling } \\
\hline
\end{tabular}

Figure 1. The General Strucure of Traditional University Student Management System

\section{The Proposed and Designed Methodology}

The Perspective of Humanistic Care. As far as the university students' management, whether in the determination of plan and tasks, and the choice of content and form, comes from the management object that students understanding and grasp, originated from the various contradictions in the process of students' development of deep insight. The need of 
different individuals in the whole group and is not exist in isolation, they are interrelated and interact. In terms of student management in colleges and universities good management effect is not direct or completely produced in management itself, the management object management environment of the students about their feelings, to oneself in the school host status from the understanding of these factors, and the insight and understanding of university students' management became a madrassa reflected, nonexistent. Therefore, we only consider the individual situation of students, attach importance to personal needs in the management of the status and function, and use them as a movement, change, student management in colleges and universities to target, so as to improve the efficiency of management, have the desired effect. It is the important place to cultivate talents in colleges and universities, colleges and universities student management work a direct impact on the cultivation of talents. Therefore, China attaches great importance to the student management work in colleges and universities, put a lot of manpower and material resources and build a set of management system and achieved some results.

At present, the problems appear in the student management work in colleges and universities, world-wide, most is that people didn't work well, not management concepts backward, not competent, is improper management method, perpetuated this misunderstanding, or there is no college students as the core, in the process of management in the management goal deviation, etc. This violates the humanism theory in different extent. To this end, should absorb the essence of the humanistic theory and in colleges and universities student management work in efforts to implement and execute. (1) Set up the correct view about people. Actually college students are not only the object of management, as well as the main body of management. Because university students' management in the final analysis is the management of college students, from the management decision-making, organization, implementation to the realization of the target, relies on college students. (2) Clear responsibility, and strive to implement target management. Target management refers to the higher and lower management personnel of an organization and common goals, all members in the organization to achieve common goals of a management method. This requires all members to agree on general management objectives, create a conducive to the development of college students' comprehensive management goals. The introduction of management by objectives which will causes the education administrators and students together set targets for the management of college students, to strengthen the university student to the management of participation and identity of the organization's goals, internalizing students' behavior guide, make the management goal that college students will be on the target under the guidance of study and work hard, actively cooperate with the manager.

The Perspective of Moral Motivation. Education has been in our country is in the priority development strategy, and correctly using incentive theory is the cultivating socialist talents needed in the new period is the important responsibility of the student management work in colleges and universities. Incentive theory to conform to the psychology, thought and behavior characteristics of contemporary college students, at the same time of improving students' comprehensive quality, to improve the predictability and effectiveness of the management of university students. Using the target motivation, meet the development needs of students. The target of the management of university students has a certain particularity and it needs to serve the core goal of fostering talents in universities and colleges. Therefore, in the student management work, management requirements and management system, all need to closely around the goal of fostering talents in universities and colleges to carry out. Incentive 
theory by needs, motivation, behavior, and satisfy the mode, can truly from the state of inner, induce the creativity and enthusiasm of the people, is of great significance for talent training. In the management of colleges and universities, both positive and negative incentives are effective measures, a kind of the incentive effect is not only directly affect the individual, but also will affect around students and the collective. Managers with opposite model by set a positive example to intangible norms of student behavior, than those of the doctrine, curing more specific regulations, management effect is more apparent. In addition, rewards and punishment incentive which can mobilize student's enthusiasm and inspire students' inner passion which makes its active participation in the activities of the class management and learning goal setting, in the process of realization of individual value, enhancing the awareness.

Using achievement motivation, eliminate the negative impact of students. Achievement motivation is an important part of incentive theory, it basically is to guide students according to their own development needs, set up the action and broad ideal goal. Each student more than eager to rapid growth, the pursuit of progress, has a relatively strong achievement needs. In student management, therefore, managers need to correct analysis of the relationship between college students' personal and social development needs which needs to pay attention to the socialist ideological and political education of students, make them set up socialism great ideal, guide the student to carry on students learn scientific and cultural knowledge and improve personal thought unifies, to set up socialist broad ideal combined with the arduous struggle the spirit. Emphasized the moral incentive is mandatory, is potential impact on people, and it is on the basis of conform to people's psychological behavior rule, the ultimate goal is to make people conscious action.
The principles of moral motivation could be summarized as the follows. (1) Principle of fairness. So-called justice and refers to no matter who, as long as there is the correct moral behavior, you can get the corresponding incentive. Injustice is cannot produce incentive effect of motivation. Fair moral incentives to the person's moral motivation intensity and durability are had a profound influence. (2) The principle of difference. This will make moral incentive has good pertinence and effectiveness, and to pull the heartstrings of the student, obtain good effect. (3) The principle of people-oriented. All management is the management of the people, by the management of people. In student management in colleges and universities, therefore, the construction of moral motivation, must implement the people-oriented principle, to promote the all-round development of students as the starting point of all moral incentive measures and end-result, establish the subject status of the college students. (4) The principle of effectiveness. The so-called effective, that is, in the process of implementing moral incentives, grasp the correct guidance. College students have formed a strong sense of self, in specific learning, life can produce all kinds of moral needs and motivation, moral encouragement as satisfy college students' moral needs, arouse the enthusiasm of college students a kind of management means, in the process of implementation, to avoid can meet the needs of students' moral and pure from the educational target, must take student individual moral need and the educational target, the moral incentive to play the biggest incentive effect.

The Combination of Humanistic Care and the Moral Motivation. The object is a student of student management work. There is also the main body of education in colleges and universities, the work mainly exist in the process of knowledge transfer and to the service delivery process. College students' management work also has a certain particularity. It in the knowledge transfer process, through the configuration of the resources of the school, 
distribution, to promote the all-round development of students. Therefore, we must find out the education of student management work properties. Improve on thought to a certain level. The corresponding will also work to a new realm. So establish the student management work of positioning is the key of management theory innovation. Also is the starting point. Legalization is the guarantee of student work management idea innovation. On the concept of innovation from the aspect of ideological concept to the system requirements for the level of transformation, establish a strict system of student management work to specific requirements and constraints. The combination of humanistic care and the moral motivation will help the managers undertake the management work easier and more effective.

\section{Conclusion}

In this paper, we conduct research on the applications of humanistic care and the moral motivation on university student management. Key to the development of the school in not is difficult to adapt to the needs of the development of social reform school education teaching reform, in addition to the objective material guarantee students need all the staff for schools with this subjective human factors of the main human factors is students the stability of the steady all the stability; Ann is the school students. College student management work faces new situation and requirements, need to adopt new methods of education teaching management to promote the students' growing up, update education concept to promote the progress and development of the school. In this process, it is necessary to pay attention to the guidance of teacher management and student's self-management combined with each other, in colleges and universities to build an open and harmonious teaching environment, strengthen the humanism education school, and on the basis of rational management to strengthen school human based management. In the future, we plan to review more literatures to optimize the current method.

\section{References}

[1] Huai-Zhong M A. An Analysis on the Characteristics of Humanistic Education Management of American Universities:A Case Study of Lindenwood University,USA[J]. Journal of Wenshan University, 2012.

[2] Yuan L, Sang Q S. Explore about humanistic care and psychological counseling on moral education in middle school[J]. Journal of Nanchang College of Education, 2012.

[3] Zou H, Huang H. Confucius humanistic management thoughts and its enlightenment on college students management in new era[J]. Journal of Henan Institute of Science $\&$

Technology, 